O.O. Havryliuk, O.Yu. Semchuk

\title{
THEORETICAL EVALUATION OF THE TEMPERATURE FIELD DISTRIBUTION IN THE SILICON PERIODIC NANOSTRUCTURES DURING THERMAL ANNEALING
}

\author{
Chuiko Institute of Surface Chemistry of National Academy of Sciences of Ukraine \\ 17 General Naumov Str., Kyiv, 03164, Ukraine, E-mail: gavrylyuk.oleksandr@gmail.com
}

Interesting direction of investigations is using surface-periodic structures in solar cells, because micrometer and nanometer periodic structures enlarge area of solar cells surface. At this, for using in solar cells, creation is proposed of $p-n$ or $n-p$ junctions in micro-threads of those structures. Taking into consideration that creation of those junctions is to be realized under a temperature impact, necessity arouses of analyzing temperature distribution in periodic structures through heating. It makes it possible to control the alloying process more widely and to create $p$ - $n$ or $n-p$ junctions in micro-threads. In the process of thermal annealing of porous silicon, desorption of electrochemical processing products takes place on its surface and its luminescent properties change.

In this work numerical calculations are made of a temperature distribution in periodic structures on silicon surface in process of thermal annealing.

Calculations realized in the given investigation make it possible to forecast a temperature distribution in silicon periodic structures in process of thermal annealing. It gives a possibility for more precise alloying such structures. It is shown that after $40 \mu$ s the specimen gets warmed thoroughly. But a small irregular warming takes place between micro-threads that can be caused by heated air fluctuations. Distribution of the temperature profiles is shown at different time intervals. It is shown that in case of thermal annealing a span between micro-threads heats up.

Keywords: porous silicon, periodic structures, thermal annealing, thermoconductivity equation

\section{INTRODUCTION}

Nowadays, higher interest arouses to semiconductor materials with nano-dimensional structure elements that can change appreciably their traditional properties [1-3]. In our previous works heat expansion was analyzed in nonstoichiometric films $\mathrm{SiO}_{x}$ [4-6]. As a result, it was shown that after annealing the structure of the given films and their electric features were changed. At this, in some cases changes registered in these films differed appreciably. Optic features of these structures change, too, and that makes them attractive for using in solar cells.

The idea that nano-structuring homogeneous and isotropic media can create new optical properties in them was proposed many years ago [7]. Among the most effective methods of nanostructuring are thermal and laser annealing.

But only nowadays the technologies were realized for producing nano-structural materials.
For creation of optically homogeneous structures the dimensions of structural elements and distance between them should be much less than a wave-length. Changing optical features of a semiconductor while forming nano-structures and their ensembles with typical dimensions $1-10 \mathrm{~nm}$ can be caused by:

- dimensional effects

- surface effects (new electronic and phonon levels)

- local fields depending on nanostructures' forms and their quantity.

Now, creation of periodic surface structures and properties of these structures are analyzed in great scale with various methods [8-11] for using in practical work [12-15].

Interesting direction of investigations is using surface-periodic structures in solar cells, because micrometer and nanometer periodic structures enlarge area of solar cells surface. At this, for using in solar cells, creation is proposed 
of $p-n$ or $n-p$ junctions in micro-threads of those structures. Taking into consideration that creation of those junctions is to be realized under a temperature impact, necessity arouses of analyzing temperature distribution in periodic structures through heating. It makes it possible to control the alloying process more widely and to create $p-n$ or $n-p$ junctions in micro-threads.

In the process of thermal annealing of porous silicon, desorption of electrochemical processing products takes place on its surface and its luminescent properties change [16-18].

Pores that have regular right-angled forms at a reference time change their profiles in the process of heating, their walls become rough and, by degrees, lugs begin to appear on them. In course of time, those lugs increase in dimensions and in case of a great annealing time they can grow up to a continuous bridge dividing the pour into a pair of isolated parts. Dimensions of produced bridges, their thickness and disposition depend appreciably on the temperature in a porous layer $[19,20]$.

In this work numerical calculations are made of a temperature distribution in periodic structures on silicon surface in process of thermal annealing. Dimensions of periodic structures (micro-threads) are as follows: diameter $-1 \mu \mathrm{m}$, height $-1 \mu \mathrm{m}$ (Fig. 1). The temperature distribution can give information to explain structural deformations, electrical and optical features of those structures after annealing.

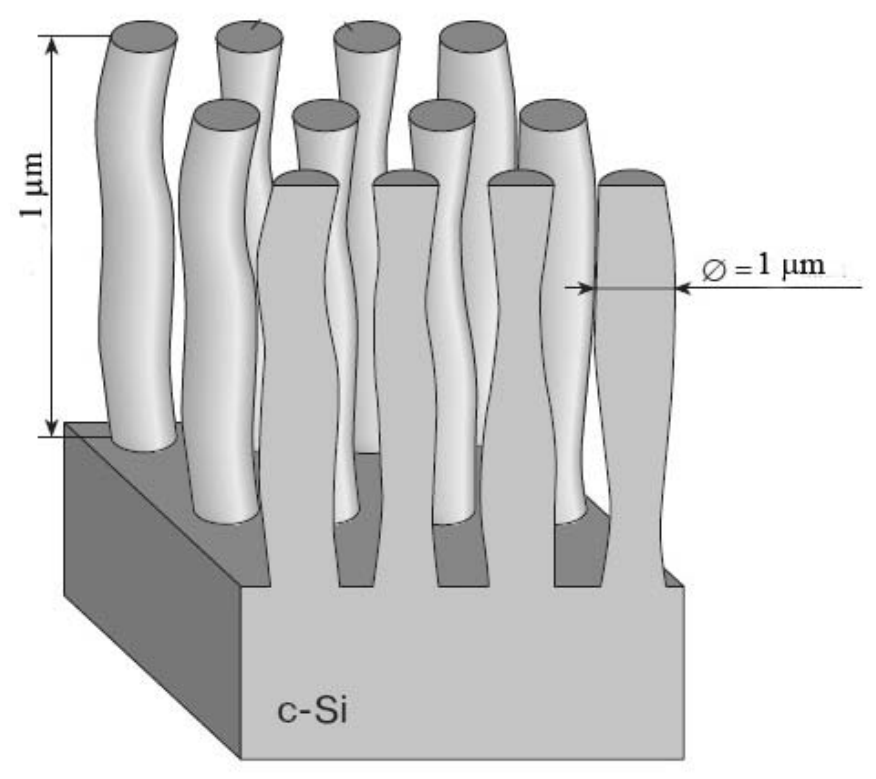

Fig. 1. Silicon periodic structure

\section{THEORY}

A heat-transfer process in a solid media is governed by the energy conservation law. The law in differential form can be exposed as [21]:

$\rho T \frac{d S}{d t}=-\operatorname{div} \vec{q}+\left(\frac{\partial Q}{\partial t}\right)$,

where $d Q=\rho T d S$ is the quantity of heat received by the volume unit of the surface, $\rho$ is the substance density. $T$ is a thermodynamic temperature, $S$ is the entropy of the media mass unit, $\vec{q}$ is the energy fluency rate translated by a heat conductivity process.

The equation given appears to be an equation of continuity for a heat quantity. Taking into consideration that $\vec{q}=-k \operatorname{grad} T$, equation (1) can be rewritten as:

$\rho c_{p} \frac{\partial T}{\partial t}=\nabla(k \nabla T)+\left(\frac{\partial Q}{\partial t}\right)$,

where $c_{p}$ is the heat capacity at constant pressure, $k$ is the coefficient of thermal conductivity. 
The distribution of temperature field on a solid body surface after the heating can be described with a differential parabolic equation (Fourier equation):

$\frac{\partial T}{\partial t}=\chi\left(\frac{\partial^{2} T}{\partial x^{2}}+\frac{\partial^{2} T}{\partial y^{2}}+\frac{\partial^{2} T}{\partial z^{2}}\right)+\frac{1}{\rho c_{p}}\left(\frac{\partial Q}{\partial t}\right)$

where $\chi=\frac{k}{\rho c_{p}}$ is the temperature conductivity,

$T$ is the sample temperature. For the problem analyzed, the equation may be expressed in form :

$\rho c_{p} \frac{\partial T}{\partial t}-\nabla[k(T) \nabla T]=Q$.
For modelling thermal heating of a periodic silicon structure in furnaces, the model is used exposed in Fig. 2.

It is considered in the model that a silicon structure is placed into a warming furnace. There is air around the structure. In such a model, heat from the furnace surface transfers to the air environment and after that - to the structure itself. On the furnace surfaces a condition of temperature stability is given:

$T=T_{0}$.

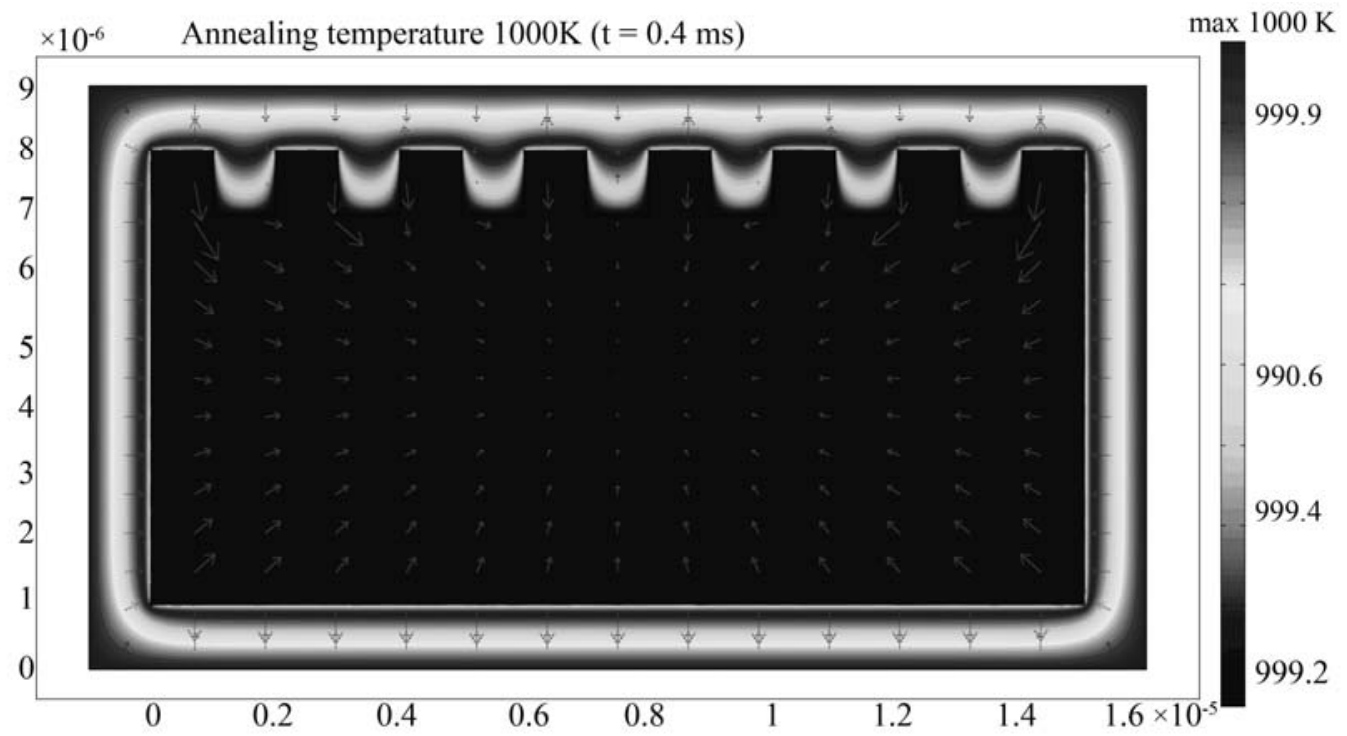

Fig. 2. Model for calculation of temperature profiles

On the specimen surface the condition assignes of heat flow continuity expressed by the equation:

$n \cdot\left(k_{1} \nabla T_{1}-k_{2} \nabla T_{2}\right)=0$.

Initial conditions are taken in form:

$$
\begin{aligned}
& T_{\text {sample }}=T_{\text {amb }}, \\
& T_{\text {airspace }}=T_{0} .
\end{aligned}
$$

With such initial conditions it is taken into consideration that the initial temperature of the specimen is equal to the temperature of environment, and the air space between the furnace walls and the specimen are to be heated up to the furnace temperature. So, the specimen is placed into the warned-up furnace.

\section{RESULTS AND DISCUSSION}

It is shown that the annealing temperature of the structure appears to be reached already after $0.5 \mathrm{~ms}$, and the heat flow is directed to the micro-thread middle on the silicon surface.

Inhomogeneous heating of periodic structures was observed at the start of annealing (Fig. 3). At first, the upper part of a micro-thread heats, then warmed air gap heats between the micro-threads, resulting in warming their vertical faces. After $30 \mu \mathrm{s}$, the surface temperature on a micro-thread reaches $530 \mathrm{~K}$, but already after $300 \mu \mathrm{s}$ the temperature is $990 \mathrm{~K}$. In the nearsurface air gap between the areas of microthreads temperatures can be slightly higher (Fig. 3).

Let's analyze a temperature distribution on a surface of periodic structures in different time 
gaps (Fig. 4). It is seen that in course of time the difference between temperatures inside microthreads and between them diminishes, that shows gradual heating of the system up to annealing temperature.

But, after more detailed calculations of temperatures in gaps between micro-threads (Fig. 5), it appears that no smooth temperature change can be fixed. It may be evidence of air fluctuation through the heating process.

Using nano-technologies makes it possible to change electronic and optical characteristics of semi-conductor nanocrystals in a wide range. The systems containing silicon nanocrystals in dielectric matrix have a perspective for creation of light-emitting systems compatible with ICdevices technology. Alloying structures of silicon nanocrystals with ions of rare-earth metals makes it possible to realize a unique process of practically entire transmission of exciton energy on ions' internal degrees of freedom. For correct alloying such structures it is necessary to know the distribution of temperature in process of heating because alloying itself takes place through the heating time. This is important essentially for changing electrical and optical properties of these structures.
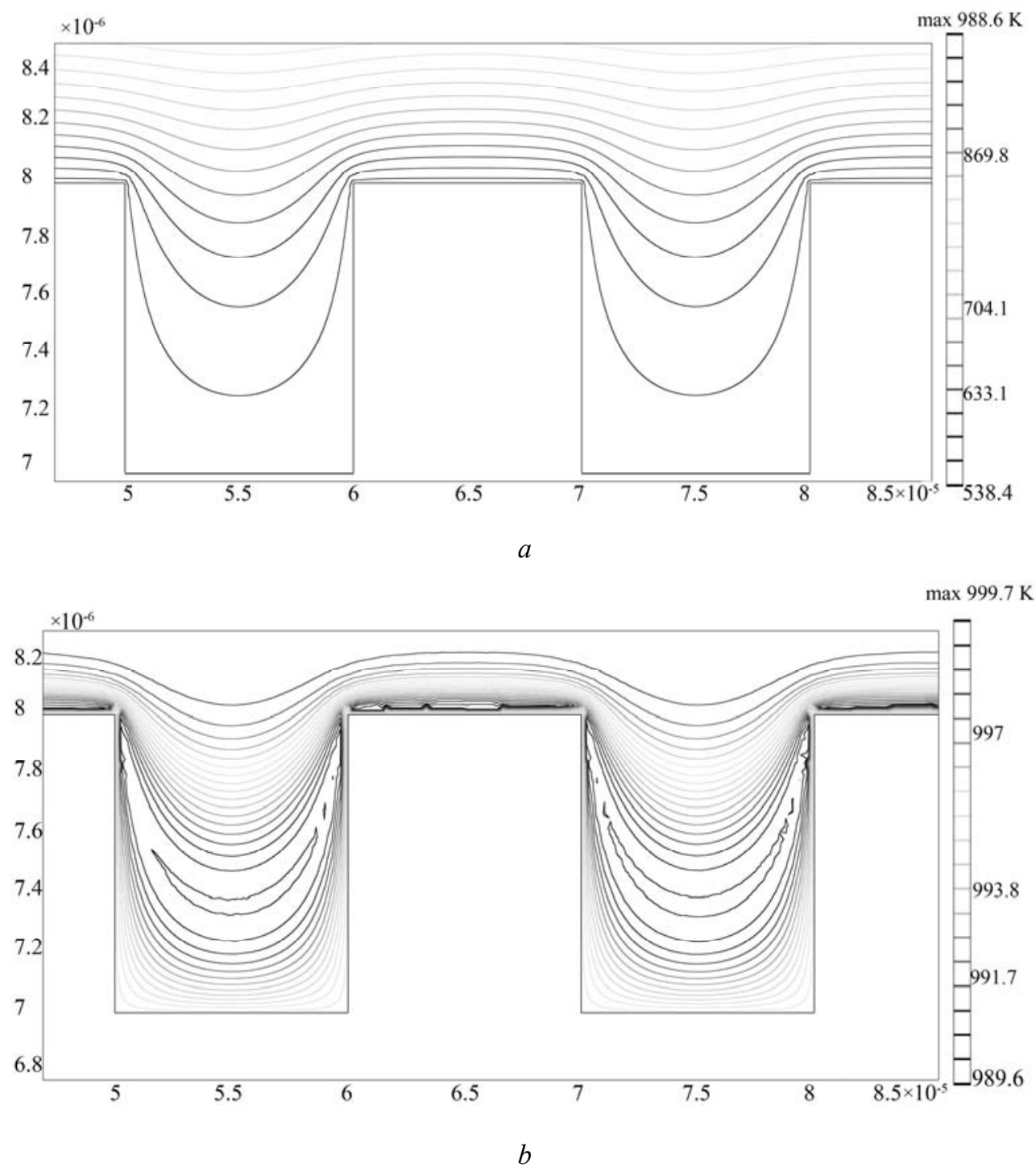

Fig. 3. The temperature profile on the micro-thread surface during thermal annealing $(T=1000 \mathrm{~K})$ : $a$-duration of annealing $30 \mu \mathrm{s}, b$-duration of annealing $300 \mu \mathrm{s}$ 


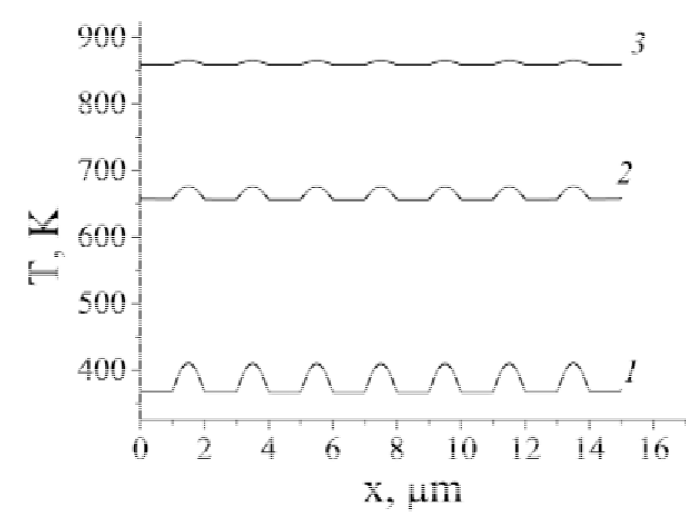

Fig. 4. Temperature distribution on a surface with periodic structure at different time moments: $1-10 \mu \mathrm{s}, 2-$ $50 \mu \mathrm{s}, 3-100 \mu \mathrm{s}$

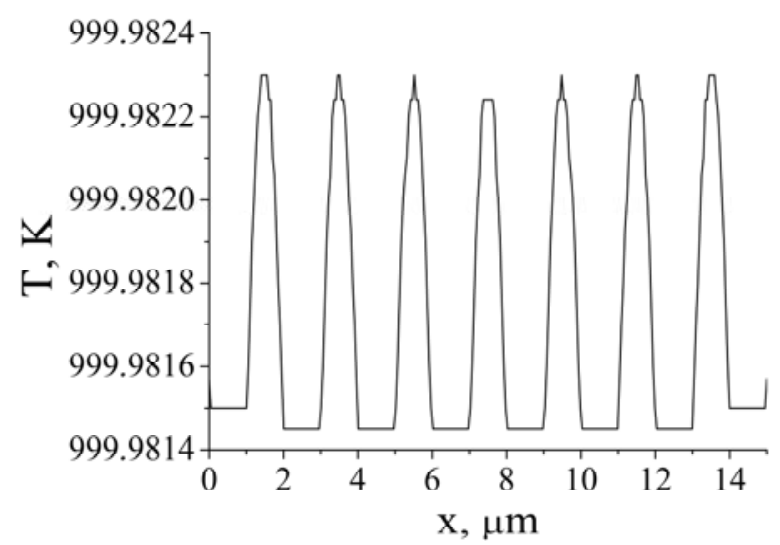

Fig. 5. Distribution of temperature on the surface of a periodic structure after $800 \mu$ s from the annealing initiation

\section{CONCLUSIONS}

Using Fourier equations and the principles proposed for its solution gives a possibility to calculate a heat distribution not only in objects-models, but in real studied structures for real experiment environment. It simplifies a process of the experimental planning and enlarges information value of the results obtained. Calculations realized in the given investigation make it possible to forecast a temperature distribution in silicon periodic structures in process of thermal annealing. It gives a possibility for more precise alloying such structures that will change their optical and electrical properties in required range. It is shown that after $40 \mu \mathrm{s}$ the specimen gets warmed thoroughly. But a small irregular warming takes place between micro-threads that can be caused by heated air fluctuations. 


\title{
Теоретичні розрахунки поширення температурного поля в кремнісвих періодичних структурах під час термічного відпалу
}

\author{
О.О. Гаврилюк, О.Ю. Семчук
}

Інститут хімії поверхні ім. О.О. Чуйка Національної академії наук України вул. Генерала Наумова, 17, Київ, 03164, Україна, oleksandr_gavrylyuk@mail.ru

Проведено математичне моделювання розподілу температури в кремнієвих періодичних структурах. Показано розподіл температурних профілів в різні проміжки часу. Встановлено час повного нагріву структури. Показано, щчо при термічному відпалі швидше нагрівається проміжок між мікронитками.

Ключові слова: пористий кремній, періодичні структури, термічний відпал, рівняння теплопровідності

\section{Теоретические расчеты распространения температурного поля в кремниевых периодических структурах при термическом отжиге}

\author{
А.А. Гаврилюк, А.Ю. Семчук \\ Институт химии поверхности им. А.А. Чуйко Наџиональной академии наук Украинь \\ ул. Генерала Наумова, 17, Киев, 03164, Украина, oleksandr_gavrylyuk@mail.ru \\ Проведено математическое моделирование распределения температуры в кремниевых \\ периодических структурах. Показано распределение температурных профилей в различные \\ промежутки времени. Установлено время полного нагрева структуры. Показано, что при \\ термическом отжиге быстрее нагревается промежуток между микронитями.
}

Ключевые слова: пористый кремний, периодические структуры, термический отжиг, уравнение теплопроводности

\section{REFERENCES}

1. Vorzobova N.D., Burunkova J.E., Bulgakov V.G. Investigation of polymeric periodical structures formation process at UV-curing composition materials by laser interference lithography method. J. Instr. Eng. 2011. 54(12): 62. [in Russian].

2. Medvid A., Dmitruk I., Onufrijevs P., Pundyk I. Properties of nanostructure formed on $\mathrm{SiO}_{2} / \mathrm{Si}$ interface by laser radiation. Solid State Phenomena. 2008. 131-133: 559.

3. Zhang Z., Wang Z., Wang D., Ding Y. Periodic antireflection surface structure fabricated on silicon by four-beam laser interference lithography. J. laser Appl. 2014. 26(1): 012010.

4. Gavrylyuk O.O., Semchuk O.Yu., Bratus O.L., Evtukh A.A., Steblova O.V., Fedorenko L.L. Study of thermophysical properties of crystalline and silicon-rich silicon oxide layers. Appl. Surf. Sci. 2014. 302: 213.

5. Steblova O.V., Evtukh A.A., Bratus' O.L., Fedorenko L.L., Voitovych M.V., Lytvyn O.S., Gavrylyuk O.O., Semchuk O.Yu. Transformation of $\mathrm{SiO}_{x}$ films into nanocomposite $\mathrm{SiO}_{2}(\mathrm{Si})$ films under thermal and laser annealing. SPQEO. 2014. 17(3): 295. 
6. Gavrylyuk O.O., Semchuk O.Yu., Steblova O.V., Evtukh A.A., Fedorenko L.L., Bratus O.L., Zlobin S.O., Karlsteen M. Influence of laser annealing on $\mathrm{SiO}_{x}$ films properties. Appl. Surf. Sci. 2015. 336: 217.

7. Born M., Wolf E. Principles of Optics. (Moscow: Nauka, 1973). [in Russian].

8. Richter J., Meinertz J., Ihlemann J. Patterned laser annealing of silicon oxide films. Appl. Phys. A. 2011. 104(3): 759.

9. Wang D., Ihlemann J., Schaaf P. Complex patterned gold structures fabricated via laser annealing and dealloying. Appl. Surf. Sci. 2014. 302: 74.

10. Bolle M., Lazare S. Characterization of submicrometer periodic structures produced on polymer surfaces with low fluence ultraviolet laser radiation. J. Appl. Phys. 1993. 73(7): 3516.

11. Gurevich E.I., Gurevich S.V. Laser induced periodic surface structures induced by surface plasmons coupled via roughness. Appl. Surf. Sci. 2014. 302: 118.

12. Heitz J., Reisinger B., Fahrner V. Laser-induced periodic surface structures (LIPSS) on polymer surfaces. In: International Conference on Transparent Optical Networks (July 2, 2012, Coventry, England). P. 1.

13. Rebollar E., Vázquez de Aldana J., Martín-Fabiani I. Assessment of Femtosecond Laser Induced Periodic Surface Structures on Polymer Films. Phys. Chem. Chem. Phys. 2013. 15: 11287.

14. Varache R. Ph.D (Chem.) Thesis. (Berlin, 2012).

15. Nayak B.K., Gupta M.C. Ultrafast laser-induced selforganized conical micro/nano surface structures and their origin. Opt. Lasers Eng. 2010. 48(10): 966.

16. Kisilev V.A., Polisadin S.V., Postnikov A.V. The change of porous silicon optical constants due to thermal annealing in vacuum. Fiz. i Tekh. Poluprovodnikov. 1997. 31(7): 830. [in Russian].

17. Golovan' L.A., Zheltikov A.M., Kashkarov P.K. Generation of the second optical harmonic in poroussilicon-based structures with a photonic band gap. JETP Lett. 1999. 69(4): 300.

18. Zacharias M., Heitmann J., Scholzet R. Size-controlled highly luminescent silicon nanocrystals: A $\mathrm{SiO} / \mathrm{SiO}_{2}$ superlattice approach. Appl. Phys. Lett. 2002. 80(4): 661.

19. Kostishko B.M., Zolotov A.V. Modeling of thermal annealing porous silicon during the presence of linear temperature gradient. In: Actual Problems of Solid-State Electronics and Microelectronics (Sept. 24, 2006, Divnomorskoye, Russia). P.177.

20. Kostishko B.M., Zolotov A.V., Atazhanov Sh.R. Comparative simula-tion of annealing of porous silicon substrate of simple cubic and dia-mond-like lattice structure. Physics of Low-Dimensional Structures. 2004. 3-4: 1.

21. Koroteev N.I., Shumay I.L. The Physics of High-power Laser Radiation. (Moscow: Nauka, 1991). [in Russian]. 